\title{
ANALISIS KETIDAKADILAN GENDER DALAM NOVEL CERITA CINTA ENRICO KARYA AYU UTAMI (KAJIAN SASTRA \\ FEMINISME) SEBAGAI ALTERNATIF BAHAN AJAR PADA MATA KULIAH KRITIK SASTRA DI PERGURUAN TINGGI
}

\author{
Hernia, Suhardi, , Indah Pujiastuti \\ Pendidikan Bahasa dan Sastra Indonesia, Universitas Maritim Raja Ali Haji \\ Pos-el: niaonya99@gmail.com
}

\begin{abstract}
Abstrak
Penelitian ini bertujuan untuk mendeskripsikan ketidakadilan gender dalam novel Cerita Cinta Enrico karya Ayu Utami dengan menggunakan kajian sastra feminis dan mendeskripsikan bahan ajar pada mata kuliah kritik sastra di perguruan tinggi. Metode penelitian yang digunakan dalam penelitian ini adalah pendekatan kualitatif jenis deskriptif. Teknik pengumpulan data yang digunakan berupa teknik dokumentasi dan teknik pustaka. Sumber data dalam penelitian ini adalah novel Cerita Cinta Enrico. Hasil penelitian ini ditemukan bentuk-bentuk ketidakadilan gender dalam novel Cerita Cinta Enrico yang terdapat dalam beberapa bagian yang meliputi: (1) bentuk ketidakadilan gender dari aspek subordinasi, (2) bentuk ketidakadilan gender dari aspek stereotipe atau pelabelan negatif, (3) bentuk ketidakadilan gender dari aspek kekerasan, (4) ketidakadilan gender dari aspek beban kerja ganda. Hasil analisis dari novel Cerita Cinta Enrico karya Ayu Utami sudah memenuhi kriteria untuk dijadikan sebagai alternatif bahan ajar pada mata kuliah Kritik Sastra di perguruan tinggi. Beberapa aspek untuk memilih bahan pengajaran sastra dengan tepat yaitu dilihat dari segi bahasa, psikologi, dan latar belakang budaya yang terdapat pada novel Cerita Cinta Enrico karya Ayu Utami.
\end{abstract}

Kata Kunci: Ketidakadilan gender, Feminisme, Novel $C C E$, Bahan ajar.

\begin{abstract}
This study aims to describe gender injustice in Ayu Utami's Love Story Enrico novel by using feminist literary studies and describing teaching materials in literary criticism in college. The research method used in this research is a descriptive qualitative approach. Data collection techniques used in the form of documentation techniques and library techniques. The data source in this study is the novel Cinta Enrico. The results of this study found forms of gender injustice in the novel Cinta Enrico contained in several sections which include: (1) forms of gender injustice from the aspect of subordination, (2) forms of gender injustice from aspects of stereotypes or negative labeling, (3) forms of injustice gender from the aspect of violence, (4) gender injustice from the aspect of multiple workloads. The results of the analysis of the novel Cinta Utrico by Ayu Utami already meet the criteria to be used as an alternative teaching material in the Literary Criticism course in college. Some aspects of choosing literary teaching materials appropriately are seen in terms of language, psychology, and cultural background contained in the novel Cinta Utrico by Ayu Utami.
\end{abstract}

Key Words: Gender injustice, Feminism, Enrico's Love Story Novel, teaching materials. 


\section{PENDAHULUAN}

Biasanya dalam kehidupaan sehari-hari perempuan selalu dinilai sebagai makhluk yang bermutu rendah dari pada laki-laki. Perempuan dianggap sebagai makhluk yang lemah sehingga harus berada di bawah kekuasaan laki-laki. Hal tersebutlah yang menimbulkan pembedaan perlakuan terhadap kaum perempuan dalam lingkungan masyarakat bahkan sampai dalam lingkungan keluarga.

Keluarga menjadi tempat pertama kali terjadinya masalah gender, masalah gender dipersoalkan, karena secara sosial telah melahirkan perbedaan peran, tanggung jawab, hak dan fungsi serta ruang aktivitas laki-laki dan perempuan dalam masyarakat. Perbedaan tersebut akhirnya membuat masyarakat cenderung membeda-bedakan dan pilih-pilih perlakuan akan akses, partisipasi, serta kontrol dalam hasil pembangunan laki-laki dan perempuan, misalnya persoalan gender yang terjadi dalam keluarga seperti peranperan yang tidak seimbang antara anggota keluarga laki-laki dan perempuan seringkali memposisikan laki-laki lebih mendapatkan hak-hak istimewa, sedangkan perempuan sebagai kaum kelas kedua, meskipun pada kelompok masyarakat tertentu hubungan yang dibangun antara laki-laki dan perempuan sudah lebih baik, tetapi jika ditelaah lebih jauh, pada sebagian besar kelompok masyarakat lainnya, hubungan yang seimbang antara laki-laki dan perempuan masih jauh dari harapan.

Selain di dalam lingkungan keluarga, posisi perempuan di bidang pendidikan dan lingkungan pekerjaan juga menjadi pilihan terakhir untuk mendapatkan layanan yang layak bagi perempuan. Oleh karena itu, di bidang pendidikan banyak perempuan yang tidak pernah mengenyam pendidikan atau buta huruf. Sedangkan di lingkungan pekerjaan, perempuan dianggap lemah, pasif, dan bergantungan kepada laki-laki, maka dari itu pemilihan pekerjaan masih berbasis gender, sehingga perempuan yang memiliki pendidikan yang tinggi pun tidak mendapatkan pekerjaan yang layak, seperti pekerjaan di bidang pelayanan jasa dan pekerjaan yang tidak banyak keterampilan, hanya sedikit perempuan saja yang menduduki jabatan sebagaimanajer atau pengambil keputusan.

Permasalahan tersebut menyebutkan bahwa perempuan hanya berfungsi sebagai seorang istri pengatur rumah tangga yang harus mengerjakan segala pekerjaan yang ada di rumah saja dan tidak memiliki keahlian di bidang lain. Dengan demikian, konsep tersebut harus diubah. Sudah waktunya perempuan dan laki-laki samasama berfungsi dalam bidang yang sama tanpa adanya batasan-batasan baik itu di lingkungan keluarga, pendidikan dan pekerjaan, maka dari itu perempuan juga harus mendapatkan kesempatan yang sama memilih dan meraih posisi yang sejajar dengan laki-laki di bidang sosial.

Selain itu, dalam kehidupan seharihari sering terjadi ketimpangan gender, contohnya kekerasan yang sering terjadi pada perempuan, perempuan diangap lemah, terjadinya pelecehan seksual, munculnya cinta sesama jenis, dan lain sebagainya. Berbagai bentuk ketimpangan gender tersebut dapat dijumpai dalam sebuah karya sastra. Salah satu contoh karya sastra yang terdapat masalah gender adalah novel yang menceritakan tentang kehidupan sosial.

Permasalahan tersebut tidak akan terjadi jika ada keadilan dan kesetaraan hubungan antara laki-laki dan perempuan dalam kehidupan bermasyarakat. Perempuan sering mengalami ketidakadilan gender dalam pergaulan sosial, hal tersebut yang membangkitkan kesadaran terhadap kaum perempuan untuk melakukan usaha-usaha demi tercapainya kesetaraan gender. 
Seperti yang sudah dipaparkan di atas, ketidakadilan gender tidak hanya terjadi dalam kehidupan sehari-hari saja, tetapi juga terjadi di dalam dunia sastra, salah satu karya sastra yang mengankat masalah gender yaitu novel Cerita Cinta Enrico karya Ayu Utami yang diterbitkan oleh Kepustakaan Populer Gramedia, di Jakarta pada tahun 2012, dengan tebal 244 halaman. Novel tersebut mengangkat kehidupan tokoh perempuan dalam kaitannya dengan pilihan hidupnya untuk menentukan takdirnya sendiri. Novel Cerita Cinta Enrico juga menceritakan tentang perempuan yang memiliki pemikiran modern pada saat zaman peperangan, perempuan yang menjadi kekuatan tersendiri bagi dua orang lakilaki yang mencintainya, dan juga menceritakan sosok perempuan yang menjadi pembicaraan orang banyak yang memiliki kaitan dengan kehidupan masa kini serta dipandang bermanfaat untuk menata kehidupan masa depan yang lebih baik, khususnya bagi perempuan.

Sudah sejak lama perempuan menjadi pusat perhatian pengarang sastra. Saat ini banyak bermunculan sastrawan yang menulis pandangan terhadap perempuan, salah satunya, Ayu Utami yang merupakan penulis perempuan yang mengangkat masalah gender dalam karyanya, yaitu novelCerita Cinta Enrico. Ayu Utami adalah seorang pengarang perempuan yang berpandangan modern dengan menggunakan seksualitas sebagai media untuk mengungkapkan masalah gender, Ayu Utami besar di Jakarta dan menamatkan kuliah di Fakultas Sastra Universitas Indonesia dan menjadi seorang aktivis jurnalis yang membuatnya berpandangan luas terhadap seksualitas dan feminisme, Ayu Utami juga salah satu novelis yang menuangkan pandangannya tentang ketidakadilan gender dalam setiap karyanya.

Berdasarkan uraian di atas, novel Cerita Cinta Enrico karya Ayu Utami akan dianalisis bentuk ketidakadilan gender dengan menggunakan kajian sastra feminisme untuk mengetahui ketidakadilan gender terhadap perempuan dalam novel tersebut. Kemudian hasil penelitian ini akan dimanfaatkan sebagai alternatif pembelajaran sastra pada mata kuliah Kritik Sastra di Perguruan Tinggi. Oleh sebab itu, perlu adanya sebuah kajian yang lebih luas tentang ketidakadilan gender khususnya dalam Novel Cerita Cinta Enrico dengan judul "Analisis Ketidakadilan Gender dalam Novel Cerita Cinta Enrico Karya Ayu Utami (Kajian Feminisme) sebagai Alternatif Bahan Ajar pada Mata Kuliah Kritik Sastra di Perguruan Tinggi.

Berdasarkan latar belakang masalah di atas maka penelitian ini bertujuan untuk mendeskripsikan bentuk-bentuk ketidakadilan gender dalam novel Cerita Cinta Enrico karya Ayu Utami dan mendeskripsikan alternatif bahan ajar pada novel Cerita Cinta Enrico karya Ayu Utami terhadap mata kuliah Kritik Sastra di Perguruan Tinggi.

Hasil dari penelitian ini diharapkan dapat memberikan beberapa manfaat baik secara teoretis maupun praktis. Hasil penelitian ini diharapkan dapat memperkaya teori-teori yang berkaitan tentang gender. Manfaat bagi peneliti yaitu dapat mengetahui sejauh mana pandanganpandangan tentang gender, baik di lingkungan sosial maupun dalam karya sastra. Bagi penulis (sastrawan) yaitu agar lebih adil dalam memandang gender, tidak hanya berpihak pada satu gender saja. Manfaat bagi dunia pendidikan yaitu menjadi alternatif pembelajaran Kritik Sastra di Perguruan Tinggi.

\section{METODE PENELITIAN}

Metode yang digunakan dalam penelitian ini yaitu pendekatan penelitian kualitatif karena penelitian yang dilakukan menghasilkan data berupa kata-kata atau kalimat yang bertujuan untuk mengungkapkan fenomena tentang apa yang diteliti dan penelitian ini juga menggunakan jenis penelitian deskriptif yaitu penelitian yang berusaha untuk 
mendeskripsikan suatu masalah yang akan diteliti. Selain itu laporan hasil penelitian berisi kutipan-kutipan data dalam bentuk kata-kata maupun kaliamat untuk memberikan gambaran deskripsi laporan.

Sumber data yang dihasilkan dalam penelitian ini berasal dari teks novel Cerita Cinta Enrico karya Ayu Utami dengan tebal halaman 244 yang diterbitkan oleh Kepustakaan Populer Granedia, Jakarta pada tahun 2012.

Penelitian ini tidak terikat pada suatu tempat, karena penelitian ini berbentuk teks sastra bisa dilakukan di mana saja. Dalam penelitian ini yang menjadi instrumen penelitian adalah peneliti sendiri dan penelitian ini dibantu oleh instrumeninstrumen pembantu berupa tabel untuk membantu mengumpulkan data.

Teknik pengumpulan data dalam penelitian ini berupa teknik dokumentasi dan teknik pustaka yaitu untuk mengumpulkan data dan mendapatkan landasan teori yang dijadikan sebagai pedoman untuk memecahkan masalah yang diteliti.

Analisis data dalam penelitian ini dilakukan dengan cara membaca novel secara keseluruhan dan berulang-ulang, menyiapkan istrumen analisis ketidakadilan gender terhadap tokoh perempuan dalam novel Cerita Cinta Enrico, memberi tanda atau kode seperti menggaris bawahi pada setiap kata-kata atau kalimat yang terdapat kesetaraan gender, setelah data terkumpul barulah menyimpulkan hasil dari penelitian tersebut.

\section{HASIL DAN PEMBAHASAN}

\section{Tabel Hasil Bentuk-Bentuk} Ketidakadilan Gender

\begin{tabular}{|c|l|l|l|l|}
\hline No & $\begin{array}{c}\text { Bagian } \\
\text { Isi Novel }\end{array}$ & \multicolumn{1}{|c|}{ Kutipan Data } & Hal & $\begin{array}{l}\text { Bentuk } \\
\text { Ketida } \\
\text { kadilan } \\
\text { Gender }\end{array}$ \\
\hline 1. & $\begin{array}{l}\text { Cerita } \\
\text { Cinta } \\
\text { Enrico } \\
\text { bagian }\end{array}$ & $\begin{array}{l}\text { Jawa } \\
\text { mengirim } \\
\text { pasukan } \\
\text { menumpas untuk }\end{array}$ & 18 & $\begin{array}{l}\text { Dari } \\
\text { aspek } \\
\text { Subor } \\
\text { dinasi }\end{array}$ \\
\hline
\end{tabular}

\begin{tabular}{|c|c|c|c|c|}
\hline & $\begin{array}{l}\text { Pembe } \\
\text { rontak } \\
\text { an }\end{array}$ & $\begin{array}{lr}\text { revolusi } & \text { ini, } \\
\text { Syrnie. } & \text { Besar- } \\
\text { besaran. } & \text { Aku } \\
\text { harus } \text { mundur } \\
\text { dari kota dan } \\
\text { bergerilya di } \\
\text { hutan-hutan. } \\
\text { Padahal kamu } \\
\text { baru } \\
\text { melahirkan..." } \\
\text { "aku ikut kamu, } \\
\text { Chat". } \\
\text { Chat: panggilan } \\
\text { sayang ibuku } \\
\text { terhadap ayahku. } \\
\text { Dari Irsad. } \\
\text { Irchat. Chat... } \\
\text { Ibuku } \\
\text { mengulangi: } \\
\text { "Aku dan anak- } \\
\text { anakikut kamu. }\end{array}$ & & \\
\hline 2. & $\begin{array}{l}\text { Cerita } \\
\text { Cinta } \\
\text { Enrico } \\
\text { bagian } \\
\text { Pantov } \\
\text { el Ibu }\end{array}$ & $\begin{array}{l}\text { Lain kali jangan } \\
\text { menumpang } \\
\text { mobil orang lain } \\
\text { lagi," } \quad \text { katanya. } \\
\text { "Nanti } \quad \text { jadi } \\
\text { omongan } \\
\text { tetangga. }\end{array}$ & 39 & $\begin{array}{l}\text { Dari } \\
\text { aspek } \\
\text { Subor } \\
\text { dinasi }\end{array}$ \\
\hline 3. & $\begin{array}{l}\text { Cerita } \\
\text { Cinta } \\
\text { Enrico } \\
\text { Perem } \\
\text { puan } \\
\text { Pahla } \\
\text { wan }\end{array}$ & 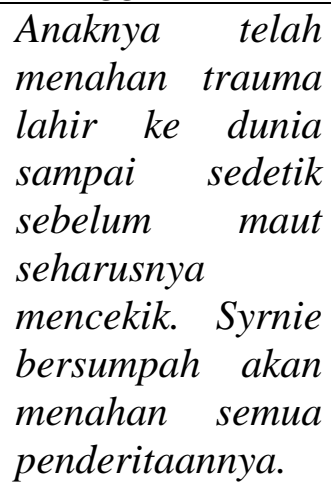 & 26 & $\begin{array}{l}\text { Dari } \\
\text { aspek } \\
\text { Keke } \\
\text { rasan }\end{array}$ \\
\hline
\end{tabular}




\begin{tabular}{|c|c|c|c|c|}
\hline 4. & $\begin{array}{l}\text { Cerita } \\
\text { Cinta } \\
\text { Enrico } \\
\text { Ayam } \\
\text { Hitam } \\
\text { dan } \\
\text { Burun } \\
\text { g } \\
\text { Kuau }\end{array}$ & $\begin{array}{l}\text { Ia berjalan pergi } \\
\text { sambil menyunggi } \\
\text { sesuatu diatas } \\
\text { kepalanya. } \\
\text { Sesuatu itu } \\
\text { adalah telur. } \\
\text { Lusinan telur, } \\
\text { untuk dijual ke } \\
\text { ibu kota provinsi, } \\
\text { yang jaraknya } \\
\text { setengah hari } \\
\text { perjalanan } \\
\text { keretaapi. }\end{array}$ & 9 & $\begin{array}{l}\text { Dari } \\
\text { aspek } \\
\text { beban } \\
\text { kerja } \\
\text { ganda }\end{array}$ \\
\hline 5. & $\begin{array}{l}\text { Cerita } \\
\text { Cinta } \\
\text { Enrico } \\
\text { Ayam } \\
\text { Hitam } \\
\text { dan } \\
\text { Burun } \\
\text { g } \\
\text { Kuau }\end{array}$ & $\begin{array}{l}\text { Maka, ibuku } \\
\text { memutuskan } \\
\text { untuk memulai } \\
\text { menjual telur dari } \\
\text { ayam-ayam yang } \\
\text { selama ini } \\
\text { dipelihara ayah } \\
\text { untuk kebutuhan } \\
\text { sehari-hari. }\end{array}$ & 10 & $\begin{array}{l}\text { Dari } \\
\text { aspek } \\
\text { beban } \\
\text { kerja } \\
\text { ganda }\end{array}$ \\
\hline
\end{tabular}

\section{PEMBAHASAN}

\section{Bentuk-Bentuk Gender \\ Ketidakadilan}

\section{a. Ketidakadilan Gender dari Aspek Subordinasi}

Subordinasi merupakan suatu anggapan terhadap gender atau penilaian terhadap suatu gender bahwa gender memiliki nilai peran yang berbeda-beda di masyarakat. Fakih (2013: 73) mengatakan bahwa, terjadinya subordinasi pada salah satu jenis kelamin, umumnya kepada kaum perempuan baik dalam rumah tangga, masyarakat maupun negara, banyak kebijakan dibuat tanpa menganggap penting kaum perempuan. Pemikiran seperti ini sudah berlangsung sejak lama, subordinasi selalu merugikan dan menimbulkan ketidakadilan terhadap perempuan. Sampai sekarang pun dalam kehidupan sehari-hari, masih ada peristiwa subordinasi, namun ada sebagian masyarakat yang menentang dan ada juga sebagian lain yang setuju bahwa suatu gender sebenarnya untuk peran tertentu saja. Adanya anggapan bahwa perempuan itu tidak penting, hal tersebut membuat kaum perempuan merasakan ketidakaadilan pada diri mereka.

Bentuk ketidakadilan yang dialami oleh tokoh ibu (Syrnie Masmirah) dari aspek subordinasi dapat dilihat melalui kutipan teks novel berikut ini:

"Jawa akan mengirim pasukan untuk menumpas revolusi ini, Syrnie. Besarbesaran. Aku harus mundur dari kota dan bergerilya di hutan-hutan. Padahal kamu baru melahirkan..."

"aku ikut kamu, Chat".

Chat: panggilan sayang ibuku terhadap ayahku. Dari Irsad. Irchat. Chat... Ibuku mengulangi: "Aku dan anak-anak ikut kamu. (hal. 18)"

Dari kutipan tersebut dikatan bahwa sebagai seorang perempuan yang cukup pandai, berpendidikan, memiliki banyak keterampilan dan sebagai seorang istri yang patuh kepada suaminya, Syrnie menghilangkan segala ego dan memutuskan untuk ikut suaminya berperang di hutan belantara. Sebagai seorang istri prajurit angkatan darat Syrnie tidak bisa menolak keputusan suaminya untuk ikut berperang bersama pasukannya. Hal ini merupakan bentuk ketidakadilan gender terhadap perempuan dari aspek subordinasi.

\section{b. Ketidakadilan Gender dari Aspek Stereotipe}

Secara umum stereotipe adalah pelabelan atau penandaan terhadap suatu kelompok tertentu. Menurut Partini (2013: 21), "Stereotipe yakni suatu pembedaan status dan peran yang diharapkan dari dua jenis kelamin. Misalnya, bahwa laki-laki dianggap mempunyai intelektualitas dan emosi yang lebih tinggi, serta menginginkan kerja yang penuh arti dengan harapan harapan yang lebih besar dari pada perempuan". Stereotipe selalu merugikan dan menimbulkan 
ketidakadilan, salah satu jenis stereotipe itu adalah yang bersumber dari pandangan gender, umumnya perempuan (Fakih, 2013: 16). Akibat dari stereotipe, banyak ketidakadilan terhadap kaum perempuan yang berakibat membatasi, menyulitkan, memiskinkan, dan merugikan perempuan. Dari adanya stereotipe inilah kaum perempuan merasakan ketidakadilan pada diri mereka.

Bentuk ketidakadilan yang dialami oleh tokoh ibu (Syrnie Masmirah) dari aspek setereotipe dapat dilihat melalui kutipan teks novel berikut ini:

"Lain kali jangan menumpang mobil orang lain lagi," katanya. "Nanti jadi omongan tetangga." (hal 39).

Pada kutipan di atas terdapat ketidakadilan gender terhadap perempuan dari aspek stereotipe, karena pada kutipan tersebut merupakan larangan suami terhadap istrinya yang pulang naik mobil orang lain padahal istrinya tidak punya pilihan lain selain mencari tumpangan untuk pulang, selain itu istrinya juga dalam keadaan sedang sakit dan merekapun tidak memiliki mobil. Hal tersebut membatasi perempuan dalam melakukan sesuatu yang mereka inginkan.

\section{c. Ketidakadilan Gender dari Aspek Kekerasan}

Kekerasan adalah serangan atau invasi terhadap fisik maupun integritas mental psikologis seseorang. Kekerasan terhadap sesama manusia pada dasarnya berasal dari berbagai sumber, namun salah satu kekerasan terhadap satu jenis kelamin tertentu yang disebabkan oleh anggapan gender. Pada dasarnya, kekerasan gender disebabkan oleh ketidaksetaraan kekuatan yang ada dalam masyarakat (Fakih, 2013: 17). Maka dari itu banyak sekali bentukbentuk kekerasan yang terjadi pada kaum perempuan.

Bentuk ketidakadilan yang dialami oleh tokoh ibu (Syrnie Masmirah) dari aspek kekerasan dapat dilihat melalui kutipan teks novel berikut ini:

"Anaknya telah menahan trauma lahir ke dunia sampai sedetik sebelum maut seharusnya mencekik. Syrnie bersumpah akan menahan seтua penderitaannya. (hal. 26)“

Kutipan di atas merupakan bentuk kekerasan yang dirasakan oleh Syrnie. Ia merasakan penderitaan setelah melahirkan bayinya. Berkat kelahiran bayinya Syrnie mendapatkan nama harum dan mendapatkan makanan di tengah hutan belantara. Meskipun Syrnie harus melawan pemberontakan, ia memutuskan untuk ikut suaminya berperang meskipun itu berbahaya baginya.

\section{d. Ketidakadilan Gender dari Aspek Beban Kerja Ganda}

Adanya anggapan bahwa kaum perempuan memiliki sifat memelihara dan rajin, serta tidak cocok untuk menjadi kepala rumah tangga, berakibat bahwa semua pekerjaan domestik rumah tangga menjadi tanggung jawab kaum perempuan (Fakih, 2013: 21). Selain mengerjakan pekerjaan rumah perempuan juga membantu mencari nafkah untuk membantu keungan keluarga bagi kalangan keluarga yang miskin. Maka dari itu perempuan mengalami beban kerja ganda baik domestik maupun publik.

Bentuk ketidakadilan yang dialami oleh tokoh ibu (Syrnie Masmirah) dari aspek beban kerja ganda dapat dilihat melalui kutipan teks novel berikut ini:

"Ia berjalan pergi sambil menyunggi sesuatu diatas kepalanya. Sesuatu itu adalah telur. Lusinan telur, untuk dijual ke ibu kota provinsi, yang jaraknya setengah hari perjalanan keretaapi. (hal. 9)"

"Maka, ibuku memutuskan untuk memulai menjual telur dari ayam-ayam yang selama ini dipelihara ayah untuk kebutuhan sehari-hari. (hal. 10)" 
Dari dua kutipan di atas tokoh ibu bekerja untuk mencari nafkah. Disini tokoh ibu selain mengurus rumah tangga ia juga harus memikul beban kerja ganda dengan menjual telur demi mencari nafkah untuk membantu ekonomi keluarga. Karena suaminya belum mendapatkan pekerjaan tetap terpaksa ibu harus membantu mencari uang untuk kebutuhan sehari-hari. Mencari nafkah adalah tugas seorang lakilaki sebagai kepala rumah tanggga. Hal ini membuat ibu sebagai kaum perempuan mengalami beban kerja. Seharusnya perempuan tidak seharusnya mencari nafkah untuk keluarga, ini merupakan bentuk ketidakadilan gender terhadap perempuan. Hal ini dipertegas dengan teori (Fakih, 2013: 21-22) yang menyatakan "di kalangan keluarga miskin beban yang sangat berat ini harus ditanggung oleh perempuan sendiri. Terlebih-lebih jika si perempuan juga harus bekerja, maka ia memikul beban kerja ganda".

\section{Alternatif Novel Cerita Cinta Enrico sebagai Bahan Ajar di Perguruan Tinggi}

Menurut Rahmanto (Rahman, 2017: 12) terdapat beberapa aspek untuk memilih bahan pengajaran sastra dengan tepat. Diantaranya dilihat dari sudut bahasa, dilihat dari segi kematangan jiwa dan latar belakang budaya. Berikut akan dijelaskan ketiga aspek yang terdapat dalam novel Cerita Cinta Enrico karya Ayu Utami.

Pertama, dilihat dari bahasa yang digunakan Ayu Utami dalam novel yang ditulisnya, Ayu menggunakan bahasa yang terkesan vulgar dalam setiap karyanya, seperti kutipan berikut:

"Aku menjelang bercinta dengan seorang perempuan dengan gairah yang tak tertahankan. Ia memakai terusan bungabunga dan kakinya kokoh. Perempuan itu ternyata adalah ibuku. Aku jadi tidak enak hati, tapi keinginanku tak terbendung juga. Kami bercinta sambil ia mengelus-elus kepalaku. (hal. 183)"
Berdasarkan kutipan di atas, dari sudut bahasa yang digunakan Ayu Utami menggunakan bahasa yang terkesan vulgar, meskipun bahasa yang digunakan terkesan vulgar novel ini bisa dijadikan sebagai bahan ajar pada tingkat perguruan tinggi. Hal ini disebabkan pada tingkat perguruan tinggi masa usia mahasiswa sudah terhitung remaja menuju dewasa (18-20 an), sudah bisa mengerti dan sudah bisa memahami bahasa yang cukup rumit. Mahmud (2012: 356) mengatakan bahwa, pada masa dewasa individu sudah mencapai puncak dari perkembangan segala kemampuannya, pengetahuannya cukup luas, kecakapannya cukup banyak sehingga perkembangannya sangat pesat.

Kedua, dari segi kematangan jiwa (psikologi), berdasarkan isi novel Cerita Cinta Enrico yang mengangkat seksualitas menggunakan bahasa yang vulgar. Secara psikologi novel Cerita Cinta Enrico boleh dibaca bagi yang berusia di atas 18 tahun (Mahasiswa), karena pada tahap ini mahasiswa sudah terhitung matang dari segi pemikiran dan sudah berminat untuk menemukan konsep-konsep abstrak dengan menganalisis suatu fenomena. Mahmud (2012: 350-354) mengatakan bahwa, masa usia kemahasiswaan (18-25 tahun) digolongkan pada masa remaja akhir sampai masa dewasa awal atau dewasa madya, masa ini merupakan pemantapan pendirian hidup. Seorang remaja pada periode ini telah memiliki kemampuan mengoordinasikan, baik secara simultan maupun berurutan seperti kemampuan berpikir mengenai sesuatu, khususnya dalam hal pemecahan masalah dengan menggunakan anggapan dasar yang relevan dengan lingkungan yang dia respons dan kapasitas menggunakan prinsip-prinsip abstrak yaitu kemampuan untuk mempelajari materi-materi pelajaran yang abstrak secara luas dan mendalam.

Maka dari itu novel ini bisa diterapkan sebagai bahan ajar sastra pada perguruan tinggi. Adapun bentuk seksualitas dalam 
novel Cerita Cinta Enrico seperti terlihat pada kutipan berikut:

"Pergaulan di sana sangat bebas. Ibuku tidak tahu bahwa aku sudah pernah berbuat itu dengan perempuan di kota sunyi ini. Ada satu cewek cantik yang sangat bangak. Aku ciuman dengannya di tepi laut di atas motorku suatu malam Minggu. (hal. 127)"

Ketiga, latar belakang budaya, dilihat dari segi latar belakang budaya novel Cerita Cinta Enrico menceritakan tentang sejarah revolusi di Indonesia, seperti pada kutipan berikut:

"Beginilah kisah hidupku dalam sejarah Indonesia. Aku lahir di hari dan kota yang sama dengan pengumuman deklarasi Pemerintahan Revolusioner Republik Indonesia, yang kelak dikenal sebagai pemberontakan PRRI: Padang, 15 Februari 1958. (hal. 12).

Kutipan di atas, menceritakan tentang kelahiran Enrico yang bertepatan dengan hari bersejarah di Indonesia. Dari kutipan tersebut mahasiswa bisa mengenang kembali sejarah Indonesia yang ada dalam novel ini. Selain menceritakan tentang sejarah Indonesia novel ini juga menceritakan tentang latar budaya kehidupan bebas yang dipilih oleh tokoh Enrico, seperti kutipan berikut:

"Begitu menjadi mahasiswa di Bandung, merdeka dari ibu, aku melakukan segala hal yang ia tidak ingin aku lakukan. Merokok, bercinta, berjudi. Terbebas dari ibuku sama artinya bagiku dengan terbebas dari hari kiamat. (hal. 193)"

Meskipun latar budaya dalam novel Cerita Cinta Enrico menceritakan tentang kehidupan bebas dan juga termasuk dalam hal seksualitas. Namun novel ini bisa dijadikan sebagai bahan ajar pada tingkat perguruan tinggi, sebab mahasiswa sudah terhitung remaja menuju dewasa, sudah bisa menilai dan memberikan kesimpulan terhadap sesuatu yang terjadi baik di kehidupan nyata maupun dalam karya sastra. Mahmud (2012: 355) mengatakan bahwa, pada masa remaja persiapan ke arah dewasa, ditandai adanya kemampuan perpikir mengenai sesuatu, khususnya dalam hal pemecahan masalah dengan menggunakan anggapan dasar yang relevan dengan lingkungan yang dia respons.

Dilihat dari ketiga aspek bahan pengajaran satra yang sudah diuraikan di atas yaitu bahasa yang digunakan, kematangan jiwa dan latar belakang budaya pada novel Cerita Cinta Enrico karya Ayu Utami, maka penelitian ini akan diterapkan sebagai bahan ajar pada mata kuliah Kritik Sastra di perguruan tinggi. Alternatif bahan ajar yang ditawarkan peneliti berupa Lembar Kerja Mahasiswa (LKM). Berdasarkan hasil analisis terhadap masalah gender dalam novel Cerita Cinta Enrico dengan menggunakan kajian sastra feminis, peneliti akan melampirkan lembar kerja mahasiswa yang sudah lengkap dengan bentuk informasi dan komponen yang ada dalam bahan ajar. Sesuai dengan teori Muhidin dan Faruk (2018: 140-141) mengatakan bahwa, bahan ajar adalah segala macam bentuk informasi yang dibutuhkan oleh mahasiswa untuk dipelajari dan bahan ajar juga memiliki komponen yang terkandung di dalamnya yang berperan sebagai isi atau materi yang harus dikuasai mahasiswa dalam pembelajaran. Penelitian ini cocok untuk dijadikan sebagai bahan ajar berbentuk Lembar Kerja Mahasiswa (LKM) di perguruan tinggi. Lembar kerja mahasiswa yang peneliti buat sesuai dengan format Rencana Pembelajaran Semester (RPS) mata kuliah Kritik Sastra materi pembelajaran Kritik Sastra Feminis. Bentuk bahan ajar yang peneliti buat terdapat capaian pembelajaran yang menjadi tujuan akhir dari kegiatan perkuliahan, kompetensi yang harus dikuasai mahasiswa setelah menyelesaikan pertemuan dalam mempelajari satu pokok bahasan, selanjutnya keterampilan berfikir yang dituntut, uraian materi, aktivitas yang 
harus dilakukan selama pembelajaran untuk mencapai kompetensi, dan yang terakhir referensi.

\section{SIMPULAN}

Berdasarkan hasil penelitian dan pembahasan tentang ketidakadilan gender pada tokoh perempuan dalam novel Cerita Cinta Enrico karya Ayu Utami, terdapat beberapa bagian-bagian di dalam novel tersebut, dan novel ini juga dapat dijadikan sebagai alternatif bahan ajar di perguruan tinggi, adapun kesimpulan dari pembahasan ketidakadilan gender dan alternatif bahan ajar di perguruan tinggi sebagai berikut:

Bentuk-bentuk ketidakadilan gender pada tokoh perempuan dalam novel Cerita Cinta Enrico karya Ayu Utami terdapat pada beberapa bagian dalam novel tersebut. Pertama, bentuk ketidakadilan gender dari aspek subordinasi yang terdapat pada empat bagian di dalam novel Cerita Cinta Enrico. Kedua, bentuk ketidakadilan gender dari aspek stereotipe atau pelabelan negatif yang terdapat pada tiga bagian di dalam novel Cerita Cinta Enrico. Ketiga, bentuk ketidakadilan gender dari aspek kekerasan yang terdapat pada enam bagian di dalam novel Cerita Cinta Enrico. Keempat, ketidakadilan gender dari aspek beban kerja ganda yang terdapat pada empat bagian di dalam novel Cerita Cinta Enrico.

DAFTAR PUSTAKA

Fakih, Mansour. 2013. Analisis Gender dan Transformasi Sosial. Yokyakarta: Pustaka Pelajar.

Mahmud. 2012. Psikologi Pendidikan. Bandung: CV Pustaka Setia.

Muhidin dan Faruq. 2018. Pengembangan Bahan Ajar. Banten: Unpam Press.

Partini. 2013. Bias Gender dalam Birokrasi. Yogyakarta: Tiara Wacana.

Rahman, A. 2017. Perspektif Gender dalam Novel Suti Karya Sapardi Djoko Damono: Tinjauan Feminis Sastra dan Implementasinya pada Pembelajaran Sastra di SMA.
Skripsi. Tidak Diterbitkan. Fakultas Keguruan dan Ilmu Pendidikan. Universitas Muhammadiyah: Surakarta.

Utami, Ayu. 2012. Cerita Cinta Enrico. Jakarta: Kepustakaan Populer Gramedia. 